\title{
ANALISIS KEBUTUHAN PADA PENGAJARAN BAHASA INGGRIS DI PG-PAUD
}

\author{
Veri Hardinansyah Dja'far \\ PGPAUD, FIP Universitas Trunojoyo Madura \\ email: hardinansyah88@gmail.com
}

\begin{abstract}
Abstrak: Analisis kebutuhan pada pengajaran bahasa inggris di PG-Paud. Bahasa Inggris untuk Tujuan Tertentu (ESP) dalam proses belajar di perguruan tinggi seringkali kurang efektif. Salah satu faktor yang berkontribusi adalah kurangnya rencana pembelajaran sehingga pembelajaran tidak relevan dengan bidang sains yang mereka mampu. Oleh karena itu, perlu mulai merencanakan pembelajaran dengan melakukan analisis kebutuhan berdasarkan kebutuhan siswa dalam pembelajaran bahasa Inggris. Penelitian ini bertujuan untuk mengetahui dan mendeskripsikan kebutuhan siswa bahasa Inggris pada program pendidikan anak usia dini. Penelitian ini dilakukan dengan menggunakan pendekatan deskriptif kualitatif. Objek penelitian ini adalah siswa kelas pendidikan anak usia dini 2016/2017 Universitas Trunojoyo Madura. Data dikumpulkan melalui kuesioner dan wawancara langsung. Data yang terkumpul diklasifikasikan sehingga kebutuhan siswa dalam pembelajaran bahasa Inggris dapat diidentifikasi, kemudian dijelaskan masing-masing. Hasil penelitian menunjukkan bahwa (1) penguasaan bahasa Inggris siswa masih relatif rendah, (2) 50\% siswa meningkatkan komunikasi lisan atau kemampuan berbicara (Speaking) dan 30\% menulis sebagai prioritas utama dalam pembelajaran bahasa Inggris untuk persiapan Mengaplikasikan pekerjaan, (3) selama belajar bahasa Inggris, siswa mengharapkan adanya peningkatan keterampilan mereka yang terkait baik lisan maupun tulisan. Berdasarkan hasil tersebut, disarankan untuk menyusun perencanaan silabus dan pengembangan materi pengajaran bahasa Inggris pada program pendidikan anak usia dini.
\end{abstract}

Kata kunci: Analisis Kebutuhan, Bahasa Inggris Untuk Tujuan Khusus, Bahan Ajar.

\begin{abstract}
Abstrack: A Need Analysis for Teaching English at Early Childhood Education Department English for Specific Purposes (ESP) learning process in higher education often administered less effectively. One of the contributing factors is the lack of learning plan so that learning is irrelevant to the field of science they are capable of. Therefore, it is necessary to start plan the learning by conducting need analysis based on students' requirement on learning English. This study aims to find and describe the needs of students of English on early childhood education program. This research was carried by using qualitative descriptive approach. The objects of this research are students of early childhood education department class of 2016/2017 Universitas Trunojoyo Madura. Data were collected through questionnaires and conducting direct interviews. The collected data were classified so that the needs of the students on learning English can be identified, then described respectively. The results showed that (1) the English mastery of students was still relatively low, (2) $50 \%$ of students placed an increase in oral communication or speaking skills (Speaking) and 30\% writing as a top priority in learning English for preparation to apply a job, (3) during learning English, students expected an improvement on their skills related to both oral and written. Based on these results, it is suggested to manage syllabus planning and the development of English teaching materials in early childhood education programs.
\end{abstract}

Key words :Need Analysis, English For Specific Purposes, Teaching Material. 
Pada usia dini perkembangan anak akan berkembang secara optimal, karena pada masa ini merupakan peletakkan dasar pertama dalam mengembangkan kemampuan fisik, kognitif, bahasa, sosial emosional, dan nilai agama moral. Usia ini sering disebut sebagai usia emas (The Golden Age), karena masa ini akan terjadi perkembangan yang pesat terhadap semua aspek perkembangan dan akan terjadi sekali dalam seumur hidup, dan tidak akan kembali lagi setelah anak-anak dewasa nantinya.

Salah satu aspek perkembangan dasar anak adalah perkembangan kognitif. Perkembangan kognitif bertujuan untuk mengembangkan kemampuan berpikir anak untuk dapat mengolah perolehan belajarnya, membantu anak untuk mengembangkan kemampuan logika matematikanya dan pengetahuan akan ruang dan waktu, serta mempunyai kemampuan untuk memilah-milah dan mengelompokkan, serta mempersiapkan pengembangan kemampuan berpikir teliti.

Perkembangan kognitif salah satunya adalah Matematika. Salah satu cabang matematika yang diajarkan di sekolah adalah geometri. Pemahaman geomteri pada anak usia dini dimulai dari kongkret ke abstrak, dari segi intuitif ke analisis, dari eksplorasi ke penugasan dalam jangka waktu yang lama serta dari tahap yang paling sederhana hingga yang tinggi. Geometri merupakan bagian dari matematika yang sering kita temui dalam kehidupan sehari-hari sepe Sebagai bahasa internasional, bahasa Inggris mempunyai peranan yang sangat penting yaitu sebagai alat komunikasi, baik lisan maupun tulis. Di Era globalisasi, bahasa Inggris menjadi bahasa pengantar dalam berbagai bidang ilmu pengetahuan. Maka dari itu bahasa Inggris menjadi salah satu pelajaran pokok bagi para pembelajar diseluruh negara, termasuk Indonesia. Di Indonesia bahasa Inggris diajarkan secara formal maupun informal. Secara formal bahasa Inggris diajarkan di setiap sekolah sebagai mata pelajaran wajib mulai dari tingkat sekolah dasar sampai sekolah menengah atas ataupun kejuruan, sedangkan di tingkat pendidikan tinggi bahasa
Inggris menjadi mata kuliah wajib. Secara informal, bahasa Inggris bisa dipelajari dengan mengikuti kursus-kursus bahasa Inggris. Untuk pengembangan pengajaran bahasa Inggris di tingkat pendidikan tinggi, model pembelajaran bahasa Inggris tidak hanya dilakukan dengan model pembelajaran bahasa Inggris secara umum (General English/GE) tetapi juga menggunakan model pembelajaran bahasa Inggris secara khusus (English For Specific Purposes/ESP).

Model pembelajaran bahasa Inggris ini harus dilakukan sesuai dengan kebutuhan sipembelajar di bidangnya masing-masing. ESP merupakan salah satu bidang linguistik terapan yang sudah berkembang dikalangan para akademisi yang berkecimpung dalam bidang pengajaran dan penggunaan bahasa Inggris sesuai dengan kebutuhan bidang ilmu dan profesi dimana bahasa Inggris digunakan, seperti halnya penggunaan bahasa Inggris di bidang Ekonomi, Hukum,Pertanian, Kedokteran. Teknik ataupun bidang yang lainnnya. Menurut Robinson (1991:3), ciri utama ESP yang membedakannya dengan GE, adalah pembelajaran yang berorientasi pada tujuan khusus, lebih spesifik dalam bidang akademi maupun profesi. Sedangkan substansi ESP dirancang dan dikembangkan berdasarkan pada konsep analisis kebutuhan (need analysis). Konsep ini berusaha menghubungkan apa yang dibutuhkan para pembelajar baik dalam bidang akademik maupun profesi. Oleh karena hal itu, ESP lebih menekankan para pembelajar pada tingkatan akademik atau pendidikan tinggi dan pada tingkat profesional atau tempat kerja.

Pentingnya dilakukannya analisis kebutuhan (need analysis) dalam ESP bertujuan agar bahasa yang diajarkan benarbenar merupakan bahasa yang dibutuhkan dalam bidang yang akan ditekuni oleh para pembelajar. Seperti halnya kegiatan pembelajaran bahasa Inggris pada Program Studi PG-PAUD Universitas Trunojoyo Madura. Selama ini bahasa Inggris menjadi 
matakuliah wajib yang diampu oleh semua mahasiswa PG-PAUD pada setiap semester ke dua atau di tahun pertama perkuliahan. Dalam satu semester tersebut, pemberian materi cenderung lebih mengarah pada kebijaksanaan pengajar bahasa Inggris. Sehingga tidak jarang pemilihan materi untuk bahan ajar lebih bersifat umum (General English), tidak sesuai dengan bidang ilmu yang sedang dipelajari. Konsekuensinya, motivasi belajar bahasa Inggris para mahasiswa PG-PAUD menjadi berkurang, rata-rata mereka menganggap matakuliah bahasa Inggris sebagai pelengkap saja karena tidak menunjang pengembangan minat atau bidang keilmuan mereka.

Merespon temuan masalah diatas, maka sangat diperlukan adanya analisis kebutuhan (need analysis) terhadap pembelajaran bahasa Inggris yang sesuai dengan kebutuhan dan minat mahasiswa, maupun bidang ilmu yang sedang mereka ampu, sehingga diharapkan hasil dari pembelajaran bahasa Inggris dengan tujuan khusus ini (ESP) bisa diterapkan dan digunakan dalam dunia kerja yang akan mereka tekuni.

Bagi Pengajar Jurusan PG-PAUD, khususnya pengajar bahasa Inggris, analisis kebutuhan (need analysis) ini bisa menjadi dasar dilaksanakannya pengembangan silabus ditahap berikutnya. Bagi mahasiswa, dengan adanya need analysis dalam ESP ini, mempengaruhi motivasi belajar mereka karena arah pembelajaran bahasa Inggris semakin jelas, relevan dan sesuai dengan bidang mereka. Dengan demikian dapat mempermudah mahasiswa dalam mempelajari bahasa Inggris, baik itu penguasaan kosakata, pelafalan, maupun struktural grammatikal bahasa Inggris.

Berdasarkan alasan tersebut, maka sangat penting diadakan penelitian tentang analisis kebutuhan (need analysis) terhadap pembelajaran bahasa Inggris dengan tujuan khusus (English For Specific Purposes) pada Program Studi PG-PAUD Universitas
Trunojoyo Madura. Hasil penelitian ini nantinya akan menjadi acuan untuk tahap penelitian berikutnya, yaitu penyusunan silabus maupun pengembangan materi bahan ajar ESP pada Program Studi PG-PAUD. Penelitian ini memfokuskan pada masalah kebutuhan para mahasiswa Program Studi PGPAUD terhadap pembelajaran bahasa Inggris pada bidang pendidikan. Berdasarkan hal itu masalah yang akan dibahas adalah:

1. Bagaimana kebutuhan terhadap bahasa Inggris pada program studi PGPAUD?

2. Bagaimana pembelajaran bahasa Inggris yang sesuai dengan Program Studi PGPAUD?

Sedangkan tujuan penelitian ini adalah untuk:

1. Menemukan kebutuhan para mahasiswa terhadap pembelajaran bahasa Inggris pada program studi PGPAUD.

2. Mendeskripsikan pembelajaran bahasa Inggris yang sesuai dengan Program Studi PGPAUD.

Selanjutnya dari hasil penelitian ini akan bermanfaat bagi mahasiswa dan pengajar bahasa Inggris pada Program Studi PGPAUD. Bagi para mahasiswa PGPAUD, hasil penelitian ini diharapkan bermanfaat, yaitu akan semakin mempermudah mereka dalam mempelajari bahasa Inggris karena pemilihan materi ada kesesuaian dengan bidang yang sedang mereka ampu (ESP). Dengan demikian para mahasiswa akan menjadi lulusan yang handal dan siap bekerja pada sekolah/lingkungan pendidikan di dalammaupun luar negeri. Bagi pihak pengajar bahasa Inggris pada Program Studi PGPAUD, hasil penelitian ini dapat dijadikan acuan untuk merumuskan silabus maupun menyusun, mengembangkan materi/bahan ajar yang sesuai dengan bidang PGPAUD. Pada skala yang lebih luas, yaitu semua program studi yang ada pada lingkup Universitas Trunojoyo Madura, penelitian ini bisa dijadikan bahan acuan untuk menganalisa kebutuhan para mahasiswa terhadap pembelajaran bahasa Inggris dengan 
tujuan khusus (ESP) sesuai dengan jurusan maupun program studi masing-masing. Sehingga pembelajaran bahasa Inggris dalam ESP pada jurusan maupun program studi masing-masing akan relevan dengan penggunaan bahasa Inggris yang mereka butuhkan di dunia kerja. Need analysis memegang peranan yang sangat penting dalam proses pendesainan maupun pengembangan pelajaran bahasa Inggris untuk tujuan ESP. Analisis kebutuhan (need analysis) bisa dianggap sebagai kombinasi antara TSA (Target Situation Analysis) dan PSA (Present Situation Analysis). Fungsi dari TSA adalah untuk mengumpulkan data ataupun informasi tentang pembelajar, tetapi bukan dari pembelajar. Sebaliknya PSA adalah untuk mendapatkan atau mengumpulkan data dari para pembelajar dengan metode kuesioner angket ataupun mengadakan interview langsung dengan para pembelajar.

Metode dan pendekatan mengenai 'need analysis' ini telah dikemukakan oleh banyak para pakar, diantaranya Hutchinson \&Waters, yangmenyatakan bahwa. 'need' harus ditentukan oleh negosiasi antara masyarakat dan para shareholders. Selanjutnya secara rinci Hutchinson and Waters' (1987: 54-56 ) mengemukan tentang definisi need, yaitu dengan mengklasifikasikan needs ke dalam target needs (apa yang pembelajar perlukan untuk dapat berkomunikasi pada target situasi) dan learning needs (apa yang pembelajar perlukan untuk dapat belajar). Selanjutnya target needs dibagi lagi menjadi: Necessities: Aspekbahasa apakah yang para pembelajar perlukan. Lacks: Apa yang belum dikuasai para pembelajar. Wants: Apa yang ingin dipelajari oleh para pembelajar. Analisa target situasi ( TSA) ini diperlukan untuk bahan dari pengajuan pertanyaan tentang target situasi dan sikap terhadap situasi dari semua para pembelajar dalam proses pembelajaran.

\section{METODE}

Metode Penelitian ini berdasarkan pada metode deskriptif dengan mengacu pada pendekatan kualitatif. Berdasarkan hal itu, penelitian ini akan menggunakan hasil kuesioner angket dari responden, yaitu mahasiswa dan pihak Program Studi PGPAUD maupun wawancara dengan shareholders sebagai data yang akan dianalisis secara deskriptif kualitatif. Selanjutnya data yang tersedia akan dianalisa sesuai dengan masalah dan tujuan dari penelitian ini. Dengan demikian tahapan-tahapan penelitian ini adalah;

1. Mengumpulkan data-data yang diperoleh dari kuesioner yan diajukan kepada mahasiswa, pihak PGPAUD tentang kebutuhan mahasiswa terhadap pembelajaran bahasa Inggris dalam ESP.

2. Mengklasifikasikan (mengelompokkan) data- data hasil kuesioner.

3. Mengidentifikasi kebutuhan pembelajaran bahasa Inggris dalam ESP berdasarkan data-data tersebut.

4. Mendeskripsikan data-data tersebut sehingga bisa menjawab permasalahan yang ada.

Penelitian ini dilaksanakan di Program Studi PGPAUD, Fakultas Ilmu Pendidikan, Universitas Trunojoyo Madura yang merupakan lembaga pendidikan tinggi dibawah Kementerian Riset, Teknologi dan Pendidikan Tinggi. Sedangkan data yang dipergunakan adalah:

a. Data primer yaitu data yang diambil dari hasil kuesioner berupa angket maupun wawancara. Data-data tersebut nantinya akan dipergunakan sebagai acuan untuk menentukan kebutuhan akan pembelajaran bahasa Inggris pada Program Studi PGPAUD dengan konsep ESP.

b. Data sekunder adalah teori yang ada, dokumen berupa jurnal, buku referensi, 
serta sumber - sumber informasi lainnya yang berkaitan atau berhubungan dengan penelitian ini.

c. Obyek penelitian ini adalah mahasiswa semester dua tahun ajaran 2016/2017 Program Studi PGPAUD Universitas Trunojoyo Madura.

Sedangkan intrumen penelitian dalam pengumpulan data adalah kuesioner atau angket. selain itu juga, peneliti juga mengadakan pretest, untuk mengetahui sejauh mana pengetahuan maupun ketrampilan penggunaan bahasa Inggris mahasiswa PGPAUD. Penilaian tidak hanya pada empat ketrampilan dasar berbahasa yang meliputi menyimak (Listening), berbicara (Speaking), membaca (Reading) dan menulis (Writing), tetapi juga pada penguasaan komponen bahasa, yaitu penguasaan kosakata, pelafalan, maupun gramatikal bahasa Inggris.

\section{HASIL DAN PEMBAHASAN}

Bahasa Inggris bagi mahasiswa Program Studi PGPAUD, Universitas Trunojoyo Madura merupakan matakuliah wajib yang harus diampu oleh setiap mahasiswa pada semester kedua dengan bobot 3 SKS yang meliputi perkuliahan teori dan praktik. Seperti halnya perkuliahan bahasa Inggris pada jurusan yang lainnya, perkuliahan bahasa Inggris pada Program Studi PGPAUD dilaksanakan pada kelas dengan jumlah mahasiswa sekitar 35-40 mahasiswa di tiap kelas. Untuk pemilihan materi perkuliahan biasanya disiapkan sendiri oleh para pengajar pengampu matakuliah bahasa Inggris berdasarkan dengan keadaan kelas, bukan pada apa yang diperlukan atau dibutuhkan oleh mahasiswa. Pada pelaksanaan perkuliahan, pengaturan dan pengawasan dari pihak PGPAUD hanya dilakukan pada penjadwalan kuliah, ujian maupun penilaian. Dengan kondisi seperti hal ini, maka perkuliahan bahasa Inggris pada Program studi PGPAUD lebih cenderung berfokus pada pengajaran dasar ketrampilan membaca serta pembahasannya berfokus pada unsur gramatikal, sedangkan untuk ketrampilan berbahasa yang lainnya, yaitu menyimak (Listening), berbicara (Speaking), maupun menulis (Writing) masih kurang.

\section{Pihak Mahasiswa Program Studi PGPAUD}

\section{Necessities dan lacks}

Pada dasarnya para mahasiswa PGPAUD Universitas Trunojoyo Madura diharapkan bisa mampu menjadi lulusan yang berkualitas, yang mampu bersaing dalam dunia kerja. Untuk memenuhi kebutuhan target (necessities) tersebut, salah satu yang menjadi kewajiban Universitas Trunojoyo Madura adalah membekali para lulusan PGPAUD dengan kemampuan berbahasa Inggris yang memadai. Hal ini tidak hanya membantu para mahasiswa dalam menyelesaikan tugas perkuliahan yang hampir semua informasi tentang bidang ilmu yang mereka ampu menggunakan teks berbahasa Inggris, tetapi nantinya juga akan sangat diperlukan mereka dalam dunia kerja, baik itu yang ada di dalam maupun di luar negeri. Selama ini hasil pengajaran bahasa Inggris untuk program studi PGPAUD UTM belum mencapai hasil yang memuaskan. Beberapa hal yang bisa menjadi faktor penyebabnya adalah keberadaan kelas (jumlah mahasiswa) yang besar, materi, jumlah sks, fasilitas yang kurang memadai dan faktor faktor non akademis lainnnya.

Untuk mengetahui lebih lanjut kemampuan bahasa Inggris mahasiswa PGPAUD, maka diadakan tes kemampuan awal (pretest). Dengan demikian akan diperoleh data tentang rata-rata tingkat kemampuan bahasa Inggris mahasiswa PGPAUD. Berdasarkan hasil pretest dapat diperoleh data bahwa $70 \%$ menunjukan bahwa kemampuan bahasa Inggris mahasiswa PGPAUD masih kurang. Jika jumlah total semua nilai dari 30 mahasiswa adalah 1902 maka diketahui bahwa nilai rata-rata 
mahasiswa adalah $1902: 30=63,4$, atau dengan angka mutu mendapatkan skor 2.00 yang dalam skor angka huruf berarti C.

Dengan demikian terlihat adanya kesenjangan antara tujuan pembelajaran bahasa Inggris yang lebih berorientasi pada English for Academic Purpose (bahasa Inggris untuk akademis) dengan kemampuan awal ('lacks') bahasa Inggris mahasiswa PGPAUD yang hasilnya masih kurang. Jika menggunakan level kemampuan bahasa Inggris, bisa diartikan bahwa tingkat kemampuan bahasa Inggris mahasiswa PGPAUD masih level dasar (elementary), padahal untuk memasuki pasar kerja dibutuhkan level menengah (intermediate). Dan untuk dunia kerja, ketrampilan berbahasa Inggris yang memadai sangat dibutuhkan, terutama saat penggunaan komputer (internet), atau surat menyurat dengan pihak asing. Bahasa Inggris juga bermanfaat ketika melakukan komunikasi atau sosialisasi dalam lembaga atau perusahaan yang melibatkan kolega-kolega yang terbiasa menggunakan bahasa Inggris, khususnya ketika ada tamu asing.

Untuk mencapai kemampuan level intermediate serta berorientasi pada persiapan menghadapi pasar kerja, sebaiknya pembelajaran bahasa Inggris pada Program studi PG-PAUD perlu dikaji lagi dengan menmpertimbangkan pada kebutuhan pasar kerja serta alokasi waktu pembelajaran yang ada.

\section{Necessities dan Wants}

Sedangkan yang berkaitan dengan'wants'( keinginan), yaitu apa yang ingin dicapai oleh para pembelajar dalam mempelajari bahasa Inggris, data kuesioner menunjukkan bahwa tujuan pembelajaran bahasa Inggris pada Program Studi PGPAUD, selain untuk belajar (40\%) untuk persiapan dan keperluan bekerja menjadi prioritas utama(60\%). Dari data tersebut, sangat jelas bahwa tujuan mahasiswa dalam pembelajaran bahasa Inggris adalah untuk persiapan memenuhi permintaan pasar kerja. Selebihnya tujuan mahasiswa dalam pembelajaran bahasa Inggris adalah untuk keperluan mempelajari (belajar) buku sumber PGPAUD yang berbahasa Inggris. Dan hampir tidak ada mahasiswa yang mempelajari bahasa Inggris untuk tujuan tertentu, misalnya untuk menghadapi ujian.

Mengacu pada data informasi itu, maka pengajaran bahasa Inggris pada Program studi PGPAUD harus selaras dengan apa yang menjadi kebutuhan bahasa Inggris di tempat kerja di mana bahasa Inggris tersebut akan digunakan. Oleh karena itu sangat diperlukan adanya pembelajaran bahasa Inggris yang berorientasi pada persiapan para lulusan untuk bersaing di pasar kerja dan membekali mahasiswa dengan kemampuan berkomunikasi yang memadai sebagaimana yang dibutuhkan pasar kerja.

Sehubungan dengan ketrampilan berbahasa, diperoleh data yang menyatakan bahwa pembelajaran ketrampilan bahasa Inggris yang lebih diminati oleh mahasiswa PGPAUD, berdasarkan urutan paling atas diperoleh data bahwa dalam pembelajaran bahasa Inggris, ketrampilan berbicara (Speaking) lebih diminati atau dibutuhkan. Kemudian diikuti ketrampilan menulis (Writing) dan menyimak (Listening). Sedangkan minat atau kebutuhan pada ketrampilan membaca (Reading) menjadi pilihan yang terakhir.

Hal ini membuktikan bahwa selama ini pembelajaran bahasa Inggris lebih banyak mengarah pada ketrampilan membaca, yaitu dengan memberikan teks bacaan pada 
mahasiswa kemudian mereka harus membaca dan menjawab pertanyaan berdasarkan teks bacaan tersebut. Sedangkan ketrampilan lainnya yang sangat dibutuhkan pada dunia kerja belum terakomodasi dengan baik. Keinginan mahasiswa (wants) yang mengarah pada peningkatan kemampuan berbicara (Speaking) ini sudah sangat sesuai dengan kebutuhan pasar kerja yang mensyaratkan ketrampilan berkomunikasi dalam bahasa Inggris.

Maka dari itu untuk pemenuhan kebutuhan target (necessities), pembelajaran bahasa Inggris pada program studi PGPAUD tidak hanya pada ketrampilan membaca (Reading), seperti yang telah dilaksanakan selama ini, tetapi juga mengutamakan ketrampilan berbicara (Speaking) dan menulis (Writing). Dengan kata lain, kebutuhan target (necessities) lebih berfokus pada ketrampilan berbicara (Speaking) dan menulis (Writing). Hal ini sesuai dengan kebutuhan pasar kerja, dimana hampir semua perusahaan menempatkan kemampuan bahasa Inggris secara lisan maupun tulis sebagai persyaratan utama dalam penerimaan karyawan.

Berdasarkan data yang diperoleh, adanya kesesuaian materi (pematerian) pembelajaran bahasa Inggris dengan bidang studi pokok mahasiswa, yaitu bidang studi PGPAUD dapat diperoleh data bahwa $13 \%$ sesuai, $30 \%$ cukup sesuai dan $57 \%$ belum sesuai dengan bidang studi yang diampu. Pemberian materi pembelajaran bahasa Inggris yang sesuai dengan bidang studi pokok mahasiswa akan sangat bermanfaat untuk mempersiapkan mahasiswa dalam menghadapipersaingan kerja. Pemenuhan'wants' ini juga akan meningkatkan motivasi mahasiswa untuk belajar bahasa Inggris karena materi yang diberikan sesuai dengan apa yang mereka inginkan. Pemberian motivasi ini sangat penting dalam kondisi pembelajaran bahasa Inggris di program studi PGPAUD, mengingat waktu yang tersedia untuk perkuliahan ini sangat terbatas. Dengan motivasi tinggi mahasiswa akan menjadi pembelajar yang mandiri yang tidak bergantung pada pertemuan di kelas. Dengan demikian diharapkan para mahasiswa mau berusaha meningkatkan kemampuan bahasa Inggris mereka dengan berbagai program, salah satunya program belajar mandiri.

Untuk menunjang tercapainya 'wants' para mahasiswa akan pembelajaran bahasa Inggris, diperlukan beberapa fasilitas yang menunjang. Dari data kuesioner yang disebarkan pada responden, diperoleh informasi bahwa rata-rata mahasiswa PGPAUD mengeluh tentang fasilitas pembelajaran bahasa Inggris yang kurang memadai atau kurang lengkap, antara lain kurangnya penggunaan laboratorium bahasa, video, dan lain sebagainya.

Hal ini bisa diatasi dengan mengadakan koordinasi dengan UPT Bahasa untuk penggunaan fasilitas tersebut diatas sehingga kegiatan pembelajaran bahasa Inggris bias terlaksana dengan baik. Selain itu dari data kuesioner juga diketahui bahwa salah satu faktor yang menjadi kurang maksimalnya pembelajaran bahasa Inggris pada kelas PAUD adalah berkaitan dengan 'class management'. Karena selama ini kegiatan pembelajaran bahasa Inggris masih kurang maksimal dan kurang efektif. Dimana dalam satu kelas pembelajaran bahasa Inggris, jumlah mahasiswa berkisar antara 30-40 mahasiswa. Jika pembelajaran bahasa Inggris lebih difokuskan pada peningkatan 
ketrampilan berbicara (Speaking), maka proses pembelajaran bahasa Inggris tidak efektif dan hasilnya tidak maksimal. Karena penguasaan ketrampilan berkomunikasi ini sangat membutuhkan intensitas latihan yang tinggi. Untuk itu perlu adanya aktivitas pembelajaran bahasa Inggris dengan kelas yang lebih kecil atau kelompokkelompok kecil. Jika hal ini diterapkan pada pembelajaran bahasa Inggris pada kelas PAUD, maka konsekuensinya akan dibutuhkan lebih dari satu tenaga pengajar, tenaga teknisi, ruang kuliah, fasilitas perkuliahan seperti penggunaan LCD, dan yang penting lagi hal ini akan menambah biaya operasional.

Pada dasarnya pelaksanaan kegiatan (aktivitas) pembelajaran bahasa Inggris yang terakomodir dengan baik akan memotivasi mahasiswa untuk lebih giat belajar. Dari data yang diperoleh, berikut ini adalah usulan-usulan dari mahasiswa PGPAUD yang disusun berdasarkan skala prioritas tentang pelaksanaan aktivitas pembelajaran bahasa Inggris.

a. Pembelajaran bahasa Inggris dilaksanakan melalui perkuliahan praktek

b. Adanya penggunaan laboratorium bahasa pada pembelajaran bahasa Inggris

c. Kegiatan pembelajaran bahasa Inggris dilaksanakan melalui media video (film), game,dll

d. Pembelajaran bahasa Inggris dilakasanakan melalui kegiatan diskusi kelompok atau berpasangan.

2. Pihak Program Studi PGPAUD

Program Studi PGPAUD merupakan program studi pada Fakultas Ilmu Pendidikan, Universitas Trunojoyo
Madura. Program studi ini didirikan pada tahun 2013. Pada program studi PGPAUD, perkuliahan dilakasanakan selama 4 tahun (8 semester), dan salah satu matakuliah wajib yang harus diampu adalah bahasa Inggris. Hal ini bertujuan agar lulusan PG PAUD memiliki ketrampilan berbahasa Inggris, yang pada era globalisasi ini telah menjadi kompentensi utama dalam dunia kerja.

Hasil wawancara dengan pihak Program studi PGPAUD dapat diketahui bahwa selama ini pembelajaran bahasa Inggris sebagai matakuliah wajib yang memiliki bobot 3 SKS untuk MKU dan 2 SKS untuk Bahasa Inggris AUD. Pada semester ini, pengajaran bahasa Inggris yang disebut juga bahasa Inggris lanjutan diberikan bobot 2 SKS yang meliputi perkuliahan teori dan perkuliahan praktek.

Selain itu, pihak program studi PGPAUD juga memberikan informasi, bahwa sangatlah diharapkan bahwa pengajaran bahasa Inggris nantinya membawa hasil yang nyata yaitu kemampuan menggunakan bahasa Inggris secara lisan maupun tulis dengan baik dan benar. Sehingga ketrampilan bahasa Inggris para lulusan PGPAUD bisa menjadi bekal atau modal untuk mendapatkan pekerjaan, mengingat banyaknya lembaga-lembaga pendidikan yang selalu menggunakan kemampuan bahasa Inggris sebagai syarat utama dalam menjaring tenaga kerjanya.

Untuk itu pihak Program studi PGPAUD mengharapkan bahwa hasil pembelajaran bahasa Inggris nantinya bisa menjadi modal bagi para lulusan PGPAUD untuk mendapatkan pekerjaan, seperti halnya ketika para lulusan harus mengaplikasikan kemampuan mereka untuk menulis surat lamaran kerja (application letter), untuk 
berkomunikasi dalam bahasa Inggris pada saat mereka menghadapi wawancara atau interview kerja (job interview). Selain itu juga kemampuan bahasa Inggris yang para lulusan PGPAUD miliki ini nantinya juga akan sangat berguna bagi mereka, yaitu sebagai nilai tambah untuk mendongkrak karier mereka.

Informasi lain yang didapat dari pihak PGPAUD adalah hal yang berkaitan dengan lapangan pekerjaan para lulusan PGPAUD. Bidang pekerjaan lulusan PGPAUD sebenarnya sangat luas, tidak hanya terbatas pada bidang pendidikan AUD saja, misalnya menjadi staf pengajar PAUD, tetapi bisa juga pada perusahaan-perusahaan umum misalnya dunia perbankan, perusahaanperusahaan asing dll.

Maka dari itu untuk pembelajaran bahasa Inggris pada Program studi PGPAUD selanjutnya harus mempertimbangkan pada kebutuhan target (necessities), seperti yang telah dibahas diatas. Sehingga pemenuhan keinginan (wants) akan tercapai, dengan demikian akan meminimalkan kekurangan (lacks) pada pembelajaran bahasa Inggris.

\section{KESIMPULAN DAN SARAN}

Bedasarkan hasil analisis dapat ditarik kesimpulan bahwa;

1. Kemampuan bahasa Inggris mahasiswa PGPAUD UTM masih relatif rendah. Hal ini berdasarkan hasil pretest dari 30 responden dengan penilaian berdasarkan standar penilaian yang berlaku di Universitas Trunojoyo Madura, yang berada pada level kemampuan baik $13,3 \%$, level kemampuan cukup $16,7 \%$ sedangkan pada level kurang $70 \%$. Data ini memperkuat temuan bahwa rata-rata kemampuan bahasa Inggris mahasiswa PGPAUD UTM masih pada tingkat kemampuan atau berada pada level kurang.

2. Menurut kebutuhan mahasiswa (wants) akan pembelajaran bahasa Inggris, 50\% mahasiswa PGPAUD menempatkan peningkatan berkomunikasi lisan atau ketrampilan berbicara (Speaking) dan $30 \%$ menulis (writing) sebagai prioritas utama dalam mempelajari bahasa Inggris untuk persiapan memasuki dunia kerja. Sedangkan selama ini pembelajaran bahasa Inggris pada program studi PGPAUD lebih banyak berfokus pada ketrampilan membaca (Reading), hal ini sesuai dengan data kuesioner yang menunjukkan bahwa 6,7\% mahasiswa PGPAUD menempatkan ketrampilan membaca sebagai tujuan mempelajari bahasa Inggris.

3. Adanya kesesuaian antara kebutuhan mahasiswa yang diinginkan dalam pembelajaran bahasa Inggris, yaitu peningkatan kemampuan dan ketrampilan berbahasa Inggris secara lisan (Speaking) maupun tulis (writing), dengan kebutuhan pasar kerja, terutama pada lembagalembaga oendidikan pengguna lulusan PGPAUD.

4. Untuk memenuhi kebutuhan pasar kerja dan keinginan mahasiswa maka perlu dibuatkan arah tujuan pembelajaran bahasa Inggris pada kelas PGPAUD UTM dengan mengutamakan peningkatan kemampua berkomunikasi baik secara lisan (Speaking) maupun tulis (Writing) disertai juga peningkatan kemampuan pemahaman textbook yang sesuai dengan bidang keilmuan mereka, yaitu bidang Pendidikan Anak Usia Dini. 
Sedangkan saran -saran untuk peningkatan pembelajaran bahasa Inggris pada kelas PGPAUD adalah;

1. Pengajaran bahasa Inggris pada program studi PGPAUD UTM perlu endapat penanganan yang lebih serius dengan memperhatikan berbagai aspek yang menentukan keberhasilan penguasaan bahasa Inggris. Pembekalan bahasa Inggris yang memadai akan membantu mahasiswa menyelesaikan tugas-tugas perkuliahan dan yang lebih penting lagi adalah membantu mereka dalam persaingan dunia kerja.

2. Untuk mencapai tujuan yang diharapkan yaitu menghasilkan lulusan PGPAUD UTM yang memiliki kemampuan dan ketrampilan bahasa Inggris serta untuk memenuhi target pasar kerja, maka sangat perlu dilaksanakan perkuliahan praktek lapangan, dimana para mahasiswa PGPAUD bisa melatih ketrampilan bahasa Inggris langsung di lapangan.

3. Pihak PGPAUD diharapkan berkoordinasi dan bekerja sama dengan pihak UPT Bahasa UTM dalam hal penggunaan fasilitas pembelajaran bahasa Inggris, terutama penggunaan laboratorium bahasa, penggunaan media (video, kaset ) dan dalam pemilihan materi. Semua itu (laboratorium bahasa, pemilihan materi maupun SAC) bisa menunjang terlaksananya pembelajaran bahasa Inggris lebih memadai dan bisa terkontrol dengan baik.

4. Adanya kerjasama antara dosen-dosen PGPAUD dengan dosen pengampu bahasa Inggris tentang pengajaran program bahasa Inggris terutama berkaitan dengan istilah-istilah (terms) dalam bidang

Pendidikan Anak Usia Dini dan Psikologi. Untuk itu, rekomendasi materi bahasaInggris untuk mahasiswa PGPAUD adalah materi pembelajaran bahasa Inggris untuk kemampuan berbicara (Speaking) ,misalnya berkaitan dengan topics :
a. Introductions/Greetings
b. Talkings about family
c. Talkings about part of body
d. Talking about colour
e. Talking about daily activity
f. Numbers
g. Presentation

Sedangkan materi pembelajaran bahasa Inggris pada kemampuan membaca (Reading), teksteks bacaan tentang;
a. What is your name?
b. Parts of body
c. Colour
d. Daily habits or activities.
e. Environtments

Dan materi pembelajaran bahasa Inggris pada kemampuan menulis (Writing) berkaitan dengan penulisan;
a. Business Letters
b. $\quad$ Features of Business Letters
c. English for Jobs: Application Letters
d. Applying for a job

\section{DAFTAR PUSTAKA}

Djajasudarma, T., F. 1993. Metode Linguistik: Rancangan Metode Penelitian dan Kajian, Bandung : PT Eresco

Dudley, E., T., \& St John, M., J. 1998. Developments in English fo specific purposes. Cambridge: Cambridge University Press. 
Hutchinson and Waters. 1987. English for specific purposes. New York: Cambridge University.

Jordan, R., R. 1997. English for academic purposes: A guide and resource book for teachers. Cambridge: Cambridge University Press.

Kayl, H. 2008. Developing an ESL Curriculum Based on Needs and Situation Analysis: A Case Study. Journal of Language and Linguistic Studies, 4 (1), 29-49 